\title{
ANALYSIS OF FERULIC ACID IN ARABICA COFFEE BEAN (COFFEA ARABICA L.) USING SOLID PHASE EXTRACTION-HIGH PERFORMANCE LIQUID CHROMATOGRAPHY
}

\section{IDA MUSFIROH*, WIWIEK INDRIYATI, MIRA LAILA NUR ABADI, MUCHTARIDI MUCHTARIDI}

Department of Pharmaceutical Analysis and Medicinal Chemistry, Faculty of Pharmacy, Universitas Padjadjaran, Jatinangor, Sumedang, Indonesia

Email: ida.musfiroh@unpad.ac.id

Received: 20 Jan 2019, Revised and Accepted: 04 Jul 2019

\section{ABSTRACT}

Objective: The purpose of this research is quantitatively analyzing of ferulic acid in the Arabica coffee bean extract from three samples with different regions (Garut, Pangalengan, Tasikmalaya, West Java Indonesia) using Solid Phase Extraction-High Performance Liquid Chromatography (SPE-HPLC) method which is validated.

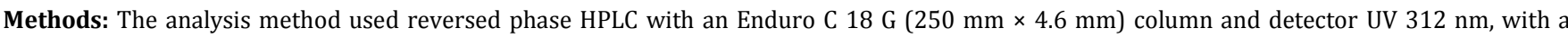
mobile phase of methanol and water containing $1 \%(\mathrm{v} / \mathrm{v})$ of acetic acid (42:58) at a flow rate of $1.0 \mathrm{ml} / \mathrm{min}$ and validation method was examined in linearity, Limit of Detection (LOD), Limit of Quantification (LOQ), precision, and accuracy.

Results: The results showed that the precision of retention was $8.853 \mathrm{~min}$, correlation coefficient (R) was 0.9996 , and the recovery was $96.909 \%$. The quantitative analysis of ferulic acid content in the extract of coffee from thus, samples of three different regions were $0.0385 \%, 0.0169 \%$ and $0.0076 \%$, respectively.

Conclusion: The analytical method was meet the validation criteria. Ferulic acid levels results from the extraction of the digestion process and pretreatment methods of Solid Phase Extraction (SPE) is $0.0385 \%$ from Garut area, $0.0169 \%$ from Pangalengan area and $0.0076 \%$ from Tasikmalaya area.

Keywords: Ferulic Acid, Arabica Coffee Beans, HPLC, SPE

(C) 2019 The Authors. Published by Innovare Academic Sciences Pvt Ltd. This is an open-access article under the CC BY license (http://creativecommons.org/licenses/by/4.0/) DOI: http://dx.doi.org/10.22159/ijap.2019v11i5.32077

\section{INTRODUCTION}

Coffee is one of the most desirable food commodities in the world. For a long time, coffee has been used as a trading ingredient since coffee can be processed into a beverage that has a delicious flavor. More than 400 billion cups are consumed each year. Currently, coffee is grown in more than 80 tropical and subtropical countries, including Indonesia $[1,2]$. Based on data from Direktorat Jenderal PPI Indonesia ranks fourth after Brazil, Vietnam and Colombia with a production of 639.305 thousand tons per year [3]. Many cultivated coffee plants in Indonesia are robusta and arabica. In the twentieth century, Indonesia was a leading producer of arabica coffee in the world market [1].

Coffee has many active compounds, one of them is polyphenols such as ferulic acid [4]. Ferulic acid is one type of phenolic acids which are found in the cell wall components, leaves and seeds of plants. The ferulic acid is produced from the metabolism of phenylalanine and tyrosine. This acid has an important role for plants because of its ability to stop the radical chain reaction. In 100 grams of arabica coffee contained ferulic acid as much as 23 to $120 \mathrm{mg}$ [4-7].

Ferulic acid has potential as anticancer, antioxidant, and antiaging. Research shows that ferulic acid can lower blood glucose and cholesterol and triglyceride levels. It also has therapeutic effects in diabetes, cardiovascular disease, anti-inflammatory, antimicrobial activity, antiallergic, antiplatelet, and antiviral $[5,6,8]$.

Ferulic acid has been quantified by many analytical methods, such as high-performance liquid chromatography (HPLC) coupled with photodiode array wavelength detector (PDA) or UV-Vis detector [913], UV-Vis spectroscopy [14, 15], thin layer chromatography [16], high-performance thin-layer chromatography [17], gas chromatography [18], chemiluminescence [19] and capillary electrophoresis [20]. However, HPLC is considered the most reliable and popular methodology for investigating phenolic acids [21-23].

The objective of this research was to develop a novel RP-HPLC method for simultaneous estimation of ferulic acid in Arabica coffee beans from three regions of West Jawa district (Pangalengan, Tasikmalaya and Garut) using Solid Phase Extraction-High Performance Liquid Chromatography (HPLC) method. This research can be used as a reference of ferulic acid level which can be developed into a product that is useful in pharmaceutical development.

\section{MATERIALS AND METHODS}

\section{Apparatus}

Blenders, vacuum, analytical balance, spatula, membrane filters, ultrasonic bath (NEY 1510), micropipette, membrane filters, 1 $\mathrm{ml}$ syringe (Terumo®), vial $(10 \mathrm{ml})$, Enduro column C-18, HPLC Dionex Ultimate $3000 \quad$ with UV detector (ultraviolet), Spektrofotometer UV (Analytik Jena specord $200 ®$ ) and various glassware that is used in Pharmacy Laboratory.

\section{Plant material}

Arabica coffee beans (Coffea arabica L.) obtained from 3 of the province at West Java, Indonesia is Pangalengan, Tasikmalaya and Garut (Specimen number.: 20/HB/10/2014). Pangalengan is a city with significant rainfall, its climate is mild and generally warm and temperate. Its temperature averages $16.1^{\circ} \mathrm{C}$. Tasikmalaya is the city with the average daily temperature are mildly varied, it ranges from $20^{\circ}$ to $34^{\circ} \mathrm{C}$ at lowland areas and $18^{\circ}$ to $22^{\circ} \mathrm{C}$ at the upland areas. While, Garut has a cool but tropical climate, with an average temperature of $24^{\circ} \mathrm{C}$.

\section{Chemical reagent}

Standard ferulic acid(Sigma-AlDrich), distilled water and double distilled water (aquabidestilata) (PT. IPHA), methanol pro HPLC (Merck), 96\% ethanol (Merck), glacial acetic acid 1\% (Merck), toluene (Merck), Feri (III) chloride, 1\% gelatin solution, ammonia liquid (Merck), Chloroform (Merck), hydrochloric acid (Merck), Mayer reagents, Dragendorff reagents, magnesium, amyl alcohol, ether, vanillin reagent, sulfuric acid, sodium hydroxide, Lieberman Buchard reagents. 


\section{Collection, determination, and processing}

The collection of material was obtained from Pangalengan, Tasikmalaya and Garut, West Jawa Indonesia. Determination was done at Herbarium Laboratory of Plant Taxonomy Department of Biology, Faculty of Mathematics and Natural Sciences, Padjadjaran University. Processing of materials was done using grinder the beans into powder form to increase the surface area before extraction.

\section{Extraction}

A total of 20 grams of seeds that have been grinded then extracted using $250 \mathrm{ml}$ aquabidestilata at a temperature of $40-50{ }^{\circ} \mathrm{C}$ for $30 \mathrm{~min}$ with a magnetic stirrer [24].

\section{HPLC conditions}

HPLC system to be used is to use Enduro C-18 column $(250 \mathrm{~mm} \times$ $4.6 \mathrm{~mm}$ ) and $312 \mathrm{~nm}$ UV detector, with a mobile phase of methanol and aquabidestilata containing $1 \%$ acetic acid with a ratio of $42: 58$ at a flow rate of $1 \mathrm{ml} / \mathrm{min}$.

\section{Mobile phase preparation}

The mobile phase that is used was methanol and aquabidestilata containing $1 \%$ acetic acid.

\section{Standard solution preparation}

A total of $25 \mathrm{mg}$ of ferulic acid standards are dissolved in $25 \mathrm{ml}$ flask with aquabidestilata to have stock solution concentration on 1000 ppm range.

\section{Sample solution preparation}

The samples that is used to do pretreatment prior to the method Solid Phase Extraction (SPE). Stationary phase SPE cartridge is activated by the stationary phase (Bakerbond-C18) passed with $9 \mathrm{ml}$ of methanol and $9 \mathrm{ml}$ of water is slowly using a vacuum. The stationary phase should remain wet. $1 \mathrm{ml}$ sample is introduced to a SPE cartridge and the vacuum is turned on, make sure the stationary phase remains wet. The filtrate should not be removed, but re-enter the filtrate into the same SPE tube, turn on the vacuum, this time drag all the fluids and collect them in different test tubes. Stream the air through an SPE tube for 3-5 min until the stationary phase is dry. After that, the ferulic acid was eluted twice with $12 \mathrm{ml}$ of absolute ethanol. SPE sample results are then dried and then reconstituted with $24 \mathrm{ml}$ aquabidest.

\section{RESULTS AND DISCUSSION}

\section{Collection, determination, and processing material}

The material test is arabica coffee that obtained from the area Pangalengan, Garut and Tasikmalaya. These three regions are the largest coffee-producing center in West Java. Determination Results that have been conducted at the Laboratory of Plant Taxonomy, Department of Biology, Faculty of Mathematics and Natural Sciences, University of Padjadjaran showed that the plants that is used in the study is the Arabica coffee plant (Coffea arabica L.) Family Rubiaceae. Processing plants is done by grinding the beans before extraction which aims to increase the surface in order to gain efficiency and rate of extraction of soluble components [25].

\section{Extraction results}

Extractions were performed using digestion method by stirring continuously at a temperature higher than room temperature, generally at a temperature of $40-50^{\circ} \mathrm{C}$ [25]. Selection of this method is intended to contain very small ferulic acid content in coffee beans can be extracted. Digestion is done by soaking 20 grams of powdered coffee beans into $250 \mathrm{ml}$ of solvent aquabidest then stirred continuously using a magnetic stirrer for $30 \mathrm{~min}$. The digestion process maintained below temperature $50{ }^{\circ} \mathrm{C}$ because Ferulic acid has stability at $50^{\circ} \mathrm{C}$ for approximately $20 \mathrm{~h}$. The reason for using Akuabides solvent because it is a solvent that readily available and cheap, non-volatile, stable, non-toxic and are commonly used general public to consume coffee. The Extraction results with digestion is liquid mass (liquid extract) with organoleptic that greenish-yellow solution to brownish green and typical aroma of coffee beans. Each liquid extract that obtained from Pangalengan, Garut and Tasikmalaya are $150 \mathrm{ml}, 160 \mathrm{ml}$, and $160 \mathrm{ml}$.

\section{Phytochemical screening results}

The phytochemical screening method was carried out with specific reagents for each group in order to know the phytochemical compounds contained in the extract of coffee beans [26, 27] as shown in table 1.

Phytochemical screening results showed that samples of arabica coffee beans of the three regions containing alkaloid metabolites, flavonoids, polyphenols, moniterpenoids, steroids, triterpenoids and quinones. This shows that differences in location of growth do not affect the presence of the womb metabolites in arabica coffee beans.

Table 1: Phytochemical screening results

\begin{tabular}{llll}
\hline Secondary metabolite & Tasikmalaya type & Garut type & Pangalengan type \\
\hline Alkaloid & + & + & + \\
Flavonoid & + & - & + \\
Tanin & - & + & + \\
Monosesquiterpenoid & + & + & + \\
Steroid & + & + & + \\
Triterpenoid & + & + & + \\
Quinone & + & - & - \\
Saponin & - & & + \\
\hline
\end{tabular}

Note (+): Detected (-): Not detected

\section{Optimization of HPLC conditions}

Optimization of HPLC conditions performed by compare several compositions of mobile phase. The choices composition used for analysis is based on some parameters. System suitability test is performed to ensure the system is running effectively and well. The parameters used include retention time, column efficiency $(\mathrm{N})$, tailing factor and column efficiency (HETP) [15]. The result shown at table 2.

Table 2: System suitability test results

\begin{tabular}{|c|c|c|c|c|c|}
\hline $\begin{array}{l}\text { Mobile phase composition (Methanol: } \\
\text { aquabidest): acetic acid 1\% }\end{array}$ & $\begin{array}{l}\text { Retention time } \\
\text { (min) }\end{array}$ & $\begin{array}{l}\text { Plate number } \\
(\mathrm{N})\end{array}$ & $\begin{array}{l}\text { HETP } \\
(\mathrm{L} / \mathrm{N})\end{array}$ & $\begin{array}{l}\text { Tailing factor } \\
\text { (T) }\end{array}$ & $\begin{array}{l}\text { Capacity factor } \\
\text { (k') }\end{array}$ \\
\hline $30: 70$ & 12.71 & 2135.112 & 0.117 & 1.10 & 5.642 \\
\hline $42: 58$ & 8.85 & 5442.75 & 0.045 & 1.04 & 3.061 \\
\hline $45: 55$ & 7.45 & 4381.85 & 0.057 & 1.00 & 2.447 \\
\hline $50: 50$ & 5.87 & 34449.21 & 0.072 & 1.00 & 1.490 \\
\hline
\end{tabular}

*System suitability test parameter column efficiency $(\mathrm{N})$, tailing factor $(\mathrm{T}), \mathrm{L}=$ Length of HPLC column $(25 \mathrm{~cm})$. Observation $(\mathrm{n}=6)$. 
From these results the selection of the conditions used was methanol and aquabidest containing $1 \%$ acetic acid (42:58) with a flow rate of $1 \mathrm{ml} / \mathrm{min}$ resulted in more efficient retention time. The retention time of $8.853 \mathrm{~min}$ was chosen to ensure that the ferulic acid standard was not covered by the irresistible retention time of the solute at $2.18 \mathrm{~min}$. In addition, this mobile phase composition has the smallest HETP value and the largest amount of theoretical chips in which the efficient column is capable of producing a narrow peak and separates the analyte well. Value plates will be even greater if the size of the longer column, this indicates that the separation process that occurs the better[16]. While HETP inversely proportional to $\mathrm{N}$ so that the column that provides the value of $\mathrm{N}$ large and small HETP value can separate the components in a sample better [28].

Results chromatogram of the methanol mobile phase composition and water which contain $1 \%$ acetic acid (42:58) at a wavelength of $312 \mathrm{~nm}$, flow rate $1 \mathrm{ml} / \mathrm{min}$ using a column of $\mathrm{C}-18$ is as follows. The peak of ferulic acid is at a retention time of $8.853 \mathrm{~min}$. as shown in fig. 1 .

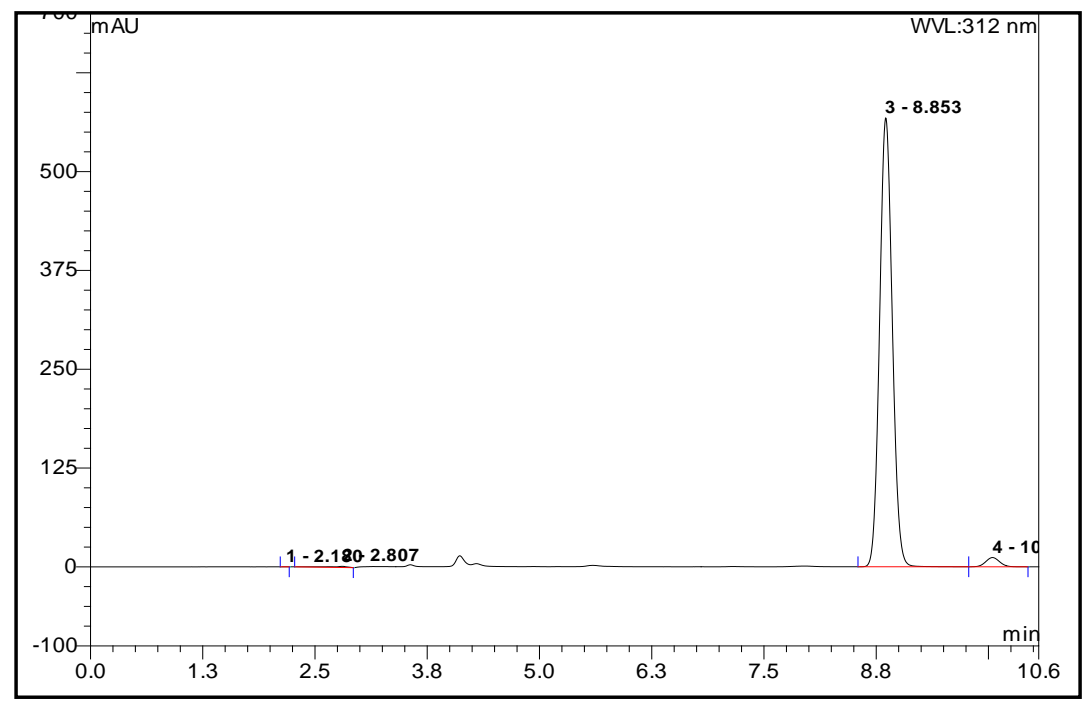

Fig. 1: Ferulic acid chromatogram in the mobile phase of methanol and water which contain $1 \%$ acetic acid (42:58)

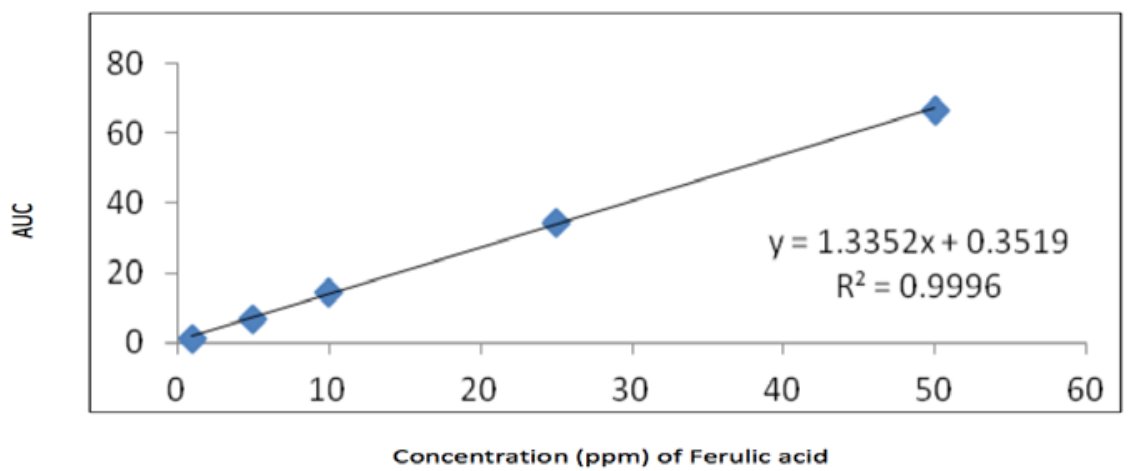

Fig. 2: Ferulic acid calibration curve

\section{Validation of HPLC analysis methods}

Linearity was studied using five concentrations of ferulic acid standard. The concentrations are $1 ; 5 ; 10 ; 25$; and $50 \mathrm{mg} / \mathrm{ml}$, each series of concentration was injected into the HPLC. The result of linearity was shown at fig. 2 .

Based on the results obtained by linear regression statistical calculation equation of the calibration curve $y=1.3352 x+0.3519$ and correlation coefficient of $\left(R^{2}\right)=0.9996$. The equation of the line which will then be used to establish the ferulic acid content. Values obtained correlation coefficient of linear is meet the requirements for valid analysis methods $>0.99$ [29].

Accuracy was obtained by determining the level of three samples with the addition of standard concentrations of ferulic acid and 1 sample without standard addition, each three repetitions $(n=3)$. Concentrations are made ie 9.6, 12 and $14.4 \mathrm{ppm}$, then do sample pretreatment by solid-phase extraction (SPE). The area gained incorporated into the linear regression equation of the calibration curve. \% Recovery is then determined using the formula:

$$
\text { Recovery }(\%)=\frac{\mathrm{C} 1-\mathrm{C} 0}{\mathrm{C} 2} \mathrm{X} 100 \%
$$

Information:

C1 = sample concentration with the spike

$\mathrm{C} 0=$ sample concentration without spike

$\mathrm{C} 2=$ the true concentration of the standard solution

In table 3 shows that the value of accuracy is expressed in $\%$ recovery of samples obtained in a row that is $93.276 \%, 104.6 \%$, and $92.853 \%$ where the value is in accordance with the requirements of $80-120 \%$ [29-32]. 
Table 3: Results of accuracy determination

\begin{tabular}{llll}
\hline Concentration (ppm) & AUC & Concentration founded (ppm) & \% Recovery \pm SD (n=3) \\
\hline 0 & 0.3692 & 0.0130 & - \\
& 0.3639 & 0.0090 \\
& 0.3538 & 0.0048 \\
9.6 & 0.8555 & 9.0521 & $95.34 \pm 1.06$ \\
& 0.8667 & 9.2534 \\
12 & 0.8627 & 9.1815 \\
& 1.0487 & 12.5249 \\
& 1.0487 & 12.9005 & $106.32 \pm 1.75$ \\
14.4 & 1.0683 & 12.8772 \\
& 1.1090 & 13.6087 \\
& 1.1149 & 13.7184 & $94.28 \pm 1.00$ \\
\end{tabular}

*Accuracy value is represented as \% recovery of 3 observation $(n=3)$ each concentration.

Precision study way studied Ferulic acid standard solution was made into 3 concentration was measured by HPLC respectively of 3 repetitions in the same day. The calculated precision value is expressed with a relative standard deviation (RSD) response of $\leq 2.0 \%$ with the equation

$$
\% \mathrm{RSD}=\frac{\mathrm{SD}}{\mathrm{X}}
$$

Information:

$\mathrm{RSD}=$ relative standard deviation

$\mathrm{SD}=$ standard deviation

$\mathrm{X}=$ average

The result of precision value based on the area expressed as RSD (\%) is $0.317076 \%$ where the value is in accordance with the requirements of $<2 \%$ [30] as shown in table 4

\section{Result of ferulic acid analysis in arabica coffee bean extract}

The determination of ferulic acid levels was performed by injecting the pre-treated sample with SPE into HPLC columns under optimized and validated conditions. The results of the analysis of the chromatograms obtained in the form that can then be calculated from the levels seen widely Area Under the Curve (AUC) at a retention time ferulic acid.

Based on the data in table 5, it can be seen that the levels of ferulic acid in coffee bean extract that comes from Garut more than Tasikmalaya and Pangalengan. Ferulic acid levels in coffee bean extract is $0.0385 \%$ from Garut area, $0.0169 \%$ from Pangalengan area and $0.0076 \%$ from Tasikmalaya area.

From table 5 showed that the levels of ferulic acid in coffee bean extract from Garut have the highest levels compared to Pangalengan and Tasikmalaya. This Content difference can be caused due to differences location of the three arabica coffee beans grow. Ideally, Arabica beans grow at temperatures between $15-24{ }^{\circ} \mathrm{C}$ and receive rainfall about $15-30 \mathrm{~cm}$ per year. In addition, the growth of coffee under the auspices of trees is one of the basic principles in coffee planting system traditionally because it can reduce excessive light [33]. So that differences in climatic conditions, rainfall in Garut, Pangalengan, and Tasikmalaya will affect the quality and quantity of the content in arabica coffee beans.

Table 4: Precision test results based on total area

\begin{tabular}{lll}
\hline Concentration $(\boldsymbol{\mu g} / \mathbf{m l})$ & Mean \pm SD $(\mathbf{n}=3)$ & \% RSD \\
\hline 5 & $4.8888 \pm 0.16$ & 0.33 \\
10 & $10.4801 \pm 0.04$ & 0.39 \\
25 & $25.3915 \pm 0.06$ & 0.22 \\
\hline
\end{tabular}

*Precision value is represented as \% recovery of 3 observation $(n=3)$ each concentration, LOD and LOQ value ferulic acid assay were calculated statistically based on the equation of the calibration curve area under the peak area ratio. The results of LOD and LOQ value were 1.266 ppm and 3.835 ppm, respectively.

Table 5: Results of quantification of ferric acid in sample

\begin{tabular}{llll}
\hline Plant origin & AUC & Conc. (ppm) & Content (\%) \pm SD (n=3) \\
\hline Pangalengan & 1.1809 & 14.90 & $0.017 \pm 0.003$ \\
& 1.1746 & 14.79 & $0.008 \pm 0.003$ \\
Tasikmalaya & 09539 & 10.82 & \\
& 0.8524 & 9.00 & $0.038 \pm 0.002$ \\
Garut & 0.6185 & 4.79 & \\
& 0.6042 & 29.2 & 32.6 \\
\hline
\end{tabular}

*Content ferulic acid each plant origin was observed by three replications $(n=3)$

\section{CONCLUSION}

The results showed that ferulic acid analysis method by HPLC (High Performance Liquid Chromatography) at the optimum condition that is using Enduro C-18 column with a mobile phase ratio of methanol: aqua-bidestilat that contains $1 \%$ acetic acid 42:58, the maximum wavelength of $312 \mathrm{~nm}$, and a flow rate of 1 $\mathrm{ml} / \mathrm{min}$ meets the requirements of the validation parameter. Ferulic acid levels results from the extraction of the digestion process, and pretreatment methods of Solid Phase Extraction (SPE) is 
$0.0385 \%$ from Garut area, $0.0169 \%$ from Pangalengan area and $0.0076 \%$ from Tasikmalaya area.

Further research is needed to optimize the analysis of ferulic acid content in coffee beans from various regions in Indonesia so that it can be used in the development of pharmaceutical preparations of the Arabica coffee bean extract (Coffea arabica L.).

\section{ACKNOWLEDGMENT}

This research was supported by the Ministry of Research, Technology and Higher Education, Indonesia.

\section{AUTHORS CONTRIBUTIONS}

All the authors have contributed equally

\section{CONFLICT OF INTERESTS}

Declared none

\section{REFERENCES}

1. AAK. Cultivation of coffee. Yogyakarta: Canisius Publisher; 1998. p. 11, 16, 20.

2. Kuit, Michiel, Thiet, Nguyen Van, Jansen, Don. Coffee Handbook: A manual for arabica cultivation. Quang Tri: Tan Lam Agricultural product Joint Stock Company; 2004.

3. Ministry of Trade. Direktorat Jenderal Perudingan Perdagangan Internasional; 2018. Available from: http://ditjenppi. kemendag.go.id/index.php/apec-oi/organisasi-komoditiinternasional/ico [Last accessed on 10 May 2019].

4. Mahatmal R, M Sangeetha. Studies on the growth, characterization, physicochemical properties and anti-bacterial activity of ferulic acid crystals. Int J Pharm Pharm Sci 2016;8:121-6.

5. Brenelli, Livia de P, Goldbeck Rosana, Dantas, Wanderley dos S, Squina Fabio M. Ferulic acid and derivatives: molecules with potential application in the pharmaceutical field. Brazil: Braz J Pharm 2013;49:395-411.

6. Shah, Rahul M Shah, Aarsh S, Shah, Mamta B. Estimation of ferulic acid in syzygium cumini seeds extract by HPLC. J Chem Pharm Sci 2012;1:201-4.

7. Kumar N, V Pruthi. Potential applications of ferulic acid from natural sources. Biotechnol Reports 2014;4:86-93.

8. Yashin Alexand ER, Yashin Yakov, Wang Jing Yuan, Nemzer Boris. Antioxidant and antiradical activity of coffee. MDPI Antioxidants 2013;2:230-45.

9. Shaikh HA, Vandana J. A novel, simple, rapid RP-HPLC method for simultaneous estimation of ferulic acid, quercetin, piperine and thymol in the ayurvedic formulation. Int J Appl Pharm 2018;6:303-8.

10. Anselmi C, Centini M, Ricci M, Buonocore A, Granata P, Tsuno T, et al. Analytical characterization of a ferulic acid $/ \gamma$-cyclodextrin inclusion complex. J Pharm Biomed 2006;40:875-81.

11. Craparo EF, Gennara C, Chiara OM, Girolamo T, Luisa BM, Gaetano G. Amphiphilic poly (hydroxyethylaspartamide) derivative based micelles as drug delivery systems for ferulic acid. J Drug Target 2009;17:78-88.

12. Kareparamban J, Nikam P, Jadhav A, Kadam V. A validated highperformance liquid chromatograhy method for estimation of ferulic acid in asafoetida and polyherbal preparation. Indian J Pharm Sci 2013;75:493-5.
13. Wang J, Cao Y, Sun B, Wang C. Characterisation of inclusion complex of trans-ferulic acid and hydroxypropyl $\beta$-cyclodextrin. Food Chem 2011;124:1069-75.

14. Lima E, Flores J, Cruz AS, Leyva Gomez G, Krotzsch E. Controlled release of ferulic acid from a hybrid hydrotalcite and its application as an antioxidant for human fibroblasts. Micropor Mesopor Mat 2013;181:1-7.

15. Merlin JPJ, Rajendra Prasad N, Shibli SMA, Sebeela M. Ferulic acid loaded poly-d,l-lactide-coglycolide nanoparticles: a systematic study of particle size, drug encapsulation efficiency and anticancer effect in nonsmall cell lung carcinoma cell line in vitro. Biomed Prev Nutr 2012;2:69-76.

16. Mabinya LV, Mafunga T, Brand JM. Determination of ferulic acid and related compounds by thin-layer chromatography. Afr J Biotechnol 2006;5:1271-3.

17. Hingse SS, Digole SB, Annapure US. Method development for simultaneous detection of ferulic acid and vanillin using highperformance thin-layer chromatography. J Anal Sci Technol 2014;5:1-9.

18. Olthof MR, Hollman PCH, Buijsman MNCP, Van Amelsvoort JMM, Katan MB. Chlorogenic acid, quercetin-3-rutinoside and black tea phenols are extensively metabolized in humans. J Nutr 2003;133:1806-14.

19. Shen G, Jia X, Jin J, Pang L, Chen Z, Du B. Determination of ferulic acid by flow injection chemiluminescence analysis based on an enhancement of the N-bromobutanimide-eosin- $\mathrm{CrCl} 3$ system in alkaline solution. Luminescence 2013;28:536-41.

20. Lima DLD, Duarte AC, Esteves VI. Optimization of phenolic compounds analysis by capillary electrophoresis. Talanta 2007;72:1404-9.

21. Barberousse H, Roiseux O, Robert C, Paquot M, Deroanne C, Blecker C. Analytical methodologies for quantification of ferulic acid and its oligomers. J Sci Food Agric 2008;88:1494-511.

22. Musfiroh I, M Mutakin, T Angelina, M Muchtaridi. Capsaicin level of various capsicum fruits. Int J Pharm Pharm Sci 2013;5:248-51.

23. Atomssa and Gholap. Characterization of caffeine and determination of caffeine in tea leaves using the uv-visible spectrometer. Afr J Pure Appl 2013;5:1-8.

24. Zain S, U Suhadi, Sawitri, U Ibrahim. Agricultural Product Handling Techniques. Bandung: Giratuna Publisher; 2005.

25. Ministry of Health of the Republic of Indonesia. Parameters General Standard Extracts Plant Medicine. First Print. Jakarta: Directorate General of Drug and Food Contro; 2000. p. 97.

26. Farnsworth NR. Biological and phytochemical screening of plants. J Pharm Sci 1966;55:243-69.

27. Lyman WJ, Reehl WF, Rosenblatt DH. Handbook of chemical property estimation methods. Washington, DC: Amer Chem Soc; 1990. p. 8-12.

28. Gandjar IG, Rohman A. Analisis kimia farmasi. Yogyakarta: Pustaka Pelajar; 2007. p. 378-399, 456-72.

29. Snyder, LR, JJ Kirkland, JL Glajch. Practical HPLC method development. 2 nd Edition. New York: John Wiley and Sons, Inc; 1997. p. 119-44, 643-728, 736.

30. Harmita. Physicochemical Analysis, Textbook Jakarta: Department of Pharmacy FMIPA UI; 2006. p. 145.

31. Harmita. Implementation guidance validation method and method calculation. Pharma Sci magazine 2005;1:117-35.

32. Beer J, Muschler R, Kass D, Somarriba E. Shade management in coffee and cacao plantations. Agroforest Syst 1998;38:139-64. 